\title{
EXERGY ANALYSIS OF A SINGLE-CYLINDER FOUR-STROKE GASOLINE ENGINE
}

\author{
${ }^{1}$ Richard Balthi MSHELIA ${ }^{(D)}$, 2 Rabo YUSUF ${ }^{(D)},{ }^{3}$ Solomon SUDI ${ }^{(i)}$ \\ 1richard.mshelia@naub.edu.ng, 2raboyusuf@thebulb.africa,3talk2sudi@gmail.com \\ 1. Department of Mechanical Engineering, Nigerian Army University Biu, Borno State, NIGERIA \\ ${ }^{2}$ Department of Mechanical Engineering, Bayero University, Kano. Kano State, NIGERIA \\ ${ }^{3}$ Department of Metallurgical and Materials Engineering, Airforce Institute of Technology, Kaduna, NIGERIA
}

Geliş/Received: 18.08.2021; Kabul/Accepted in Revised Form: 10.12.2021)

\begin{abstract}
In developing countries, the four-stroke single-cylinder gasoline engine finds wide use. Motorcycles, tricycles and household machines like vegetable grinding machines are but a few of the machinery which run on this engine. Researchers have found that this engine is inefficient and consumes a lot of fuel, in light of sustainability and energy efficiency, this study aimed to perform an exergy analysis of a single-cylinder 4-stroke gasoline engine to determine how best its efficiency can be improved. Parameters such as brake thermal power, exergy efficiency, the quantity of exergy destruction and the component of the engine which is the most influential on its efficiency were determined while varying the engine's torque. A G200K1 Honda engine was used as the study material. At the lowest tested torque of $9.4 \mathrm{Nm}$, a corresponding brake power output of $2.4609 \mathrm{~kW}$ and efficiency of $17.07 \%$ was measured, while at a higher torque $9.70 \mathrm{Nm}$, a corresponding brake power output of $2.5395 \mathrm{~kW}$ and efficiency of $17.62 \%$ was measured. It was also found that for every $1.06 \%$ rise in torque there is a corresponding $1.80 \%$ rise in brake power and exergy efficiency. It was concluded from the findings that the bulk of energy waste in the system comes from the high-temperature gas released from the engine's exhaust. For the overall efficiency of four-stroke single-cylinder gasoline engines to be improved, the exergy destruction due to combustion should be minimised by optimizing the combustion temperature and reducing heat loss from the combustion chamber.
\end{abstract}

Keywords: Exergy, Exergy Analysis, Internal Combustion Engines, Energy

\section{INTRODUCTION}

There is no doubt that the world's quest for energy has increased, this is largely because of the rise in population, technological advancement and increased earning powers. The increased quest for energy has made most countries develop policies that encourage energy conservation and energy efficiency (Aliu, 2020; Xu et al., 2021). The ability to detect energy losses is key to designing new systems that will minimize losses. In the field of thermodynamics, the ability to determine the quality of energy (exergy) in any thermodynamic system has made it easy for scientists and engineers to design systems that minimise energy losses and reduce wastages.

In practice, complete equilibrium is unattainable, any system whose parameters such as chemical composition, pressure and temperature are above that of its surroundings is not in equilibrium and possesses the capacity to carry out work, this potential is referred to as the exergy of the system. Exergy encapsulates the quality (usefulness) of energy in addition to what is destroyed during conversion from one form of energy to another (Arango-Miranda et al., 2018). Exergy is commonly referred to as useful energy or available energy. In recent years, engineers have relied on performing exergy analysis to determine the thermodynamic performance of a system/process, this has proven to be more effective than the conventional energy analysis which was previously used to determine the thermodynamic 
performance of systems, this is so because exergy analysis more details and it is more useful in improving the efficiency of a system compared to relying solely on energy analysis (Ameri et al., 2010; Rosen, 2021).

The four-stroke, single-cylinder gasoline engine has popular usage in developing countries, it finds use in diverse machinery and vehicles. In Nigeria, motorcycles and tricycles which are among the most common modes of transportation in cities and townships (Modibbo and Mary, 2017) run on 4-stroke single-cylinder gasoline engines.

The high combustion chamber temperature, heat transfer and friction in the cylinder of a typical single-cylinder four-stroke gasoline engine greatly reduce its efficiency thereby leading to high fuel (gasoline) consumption and unusually high release of greenhouse gases into the atmosphere (Liu et al., 2018; Shaheen and Lipman, 2007). This study aims to perform exergy analysis of a single-cylinder fourstroke gasoline engine to determine the most influential factor on its efficiency and how best it can be improved upon, a Honda G200K1 single-cylinder four-stroke gasoline engine located in the thermodynamics laboratory of the Department of Mechanical Engineering, Bayero University, Kano will be used for the study.

\section{MATERIALS AND METHOD}

\subsection{Experimental equipment and their uses}

An exhaust gas analyser is a equipment used to analyse the proportions of emission gases from internal combustion engines measures the proportions of $\mathrm{CO}, \mathrm{CO}_{2}$ and $\mathrm{O}_{2}$ gases in the exhaust of an IC engine while also measuring the flue and net temperatures. A Kane 900 Plus Multi-Gas Emissions Analyser was used for this study, it has a resolution of $0.10^{\circ} \mathrm{C} /{ }^{\circ} \mathrm{F}$ (Flue Temperature), $0.1^{\circ} \mathrm{C} /{ }^{\circ} \mathrm{F}$ (Inlet Temperature), $0.1 \mathrm{mbar}$ (pressure), $0.1 \%$ oxygen, $1 \mathrm{ppm}$ Carbon Monoxide (standard $\mathrm{H}$ compensated), 0.01\%Carbon Monoxide, 1ppm Nitric Oxide (standard), 1ppm Nitrogen Oxide (low range). A Vernier calliper was used for measuring the internal and external diameters of the air inlet, exhaust and fuel pipes. A Starnic calliper with a measuring range of $0-20 \mathrm{~cm}$ and a precision of $\pm 0.05 \mathrm{~mm}$ was used for this research. A hygrometer with a measurement range of $0-100 \%$, resolution of $0.1 \% \mathrm{RH}$ and accuracy of $97.5 \%$, temperature range $-20-60^{\circ} \mathrm{C}$ was used to measure the humidity of the generator house. For temperature measurements, a digital thermometer with a K-type thermocouple which has a measurement range of $-50^{\circ} \mathrm{C}$ to $1,300^{\circ} \mathrm{C}$, with an accuracy of $\pm 99.7 \%$ and a resolution of $1{ }^{\circ} \mathrm{C}$ and $0.1^{\circ} \mathrm{C}$ was used for all temperature readings. To measure the speed of air at the inlet and exhaust, a TA430/TA430 anemometer with a measuring range of 0 to $6000 \mathrm{ft} / \mathrm{min}(0$ to $30 \mathrm{~m} / \mathrm{s}$ ) and an accuracy of $\pm 0.015 \mathrm{~m} / \mathrm{s}$ was used. A TD 115 hydraulic dynamometer made by TecQuipment with a maximum load of $5000 \mathrm{~g} / 49 \mathrm{~N}$, resolution of $1 \mathrm{~g} / 0.01$ and accuracy of $\pm 0.4 \%$ was used to measure the engine torque. The speed of the engine was measured using a tachometer, the tachometer in the laboratory is a Microtech 8300 model which has an LCD screen and a measurement range of $0.3-99999$ RPM with an accuracy of $\pm 0.008 \%$. To accurately measure the volume of gasoline used for the experiment, a $500 \mathrm{ml}$ measuring cylinder with readability of $0.5 \mathrm{ml}$ and accuracy of $\pm 0.5 \mathrm{ml}$ was used.

Tests were performed on the G200K1 gasoline engine, specifications of the engine are outlined in Table 1 while its image can be seen in Figure 1. 
Table 1. Details of the Engine Used for the experiment

\begin{tabular}{|c|c|}
\hline Engine type & $\begin{array}{l}\text { 4-stroke single cylinder } \\
\text { Overhead Valve gasoline engine } \\
25^{\circ} \text { inclined cylinder } \\
\text { horizontal shaft }\end{array}$ \\
\hline Cylinder sleeve type & Cast iron sleeve \\
\hline Bore $\mathrm{x}$ Stroke & $60 \times 42 \mathrm{~mm}$ \\
\hline Displacement & $118 \mathrm{~cm}^{3}$ \\
\hline Compression ratio & $8.5: 1$ \\
\hline Net power & $2.6 \mathrm{~kW}(3.5 \mathrm{HP}) / 3600 \mathrm{rpm}$ \\
\hline Continuous rated power & $\begin{array}{l}1.8 \mathrm{~kW}(2.4 \mathrm{HP}) / 3000 \mathrm{rpm} \\
2.1 \mathrm{~kW}(2.8 \mathrm{HP}) / 3600 \mathrm{rpm} \\
\end{array}$ \\
\hline Maximum net torque & $9.3 \mathrm{Nm} / 0.74 \mathrm{kgfm} / 2500 \mathrm{rpm}$ \\
\hline Ignition system & Transistorised \\
\hline Starter & Recoil \\
\hline Fuel tank capacity & 2.0 Litre \\
\hline $\begin{array}{l}\text { Fuel consumption at continuous rated } \\
\text { power }\end{array}$ & $1.0 \mathrm{~L} / \mathrm{h}-3600 \mathrm{rpm}$ \\
\hline Engine oil capacity & 0.6 Litre \\
\hline Dimensions $(\mathrm{L} \times \mathrm{W} \times \mathrm{H})$ & $305 \times 346 \times 329 \mathrm{~mm}$ \\
\hline Dry weight & $13 \mathrm{~kg}$ \\
\hline
\end{tabular}

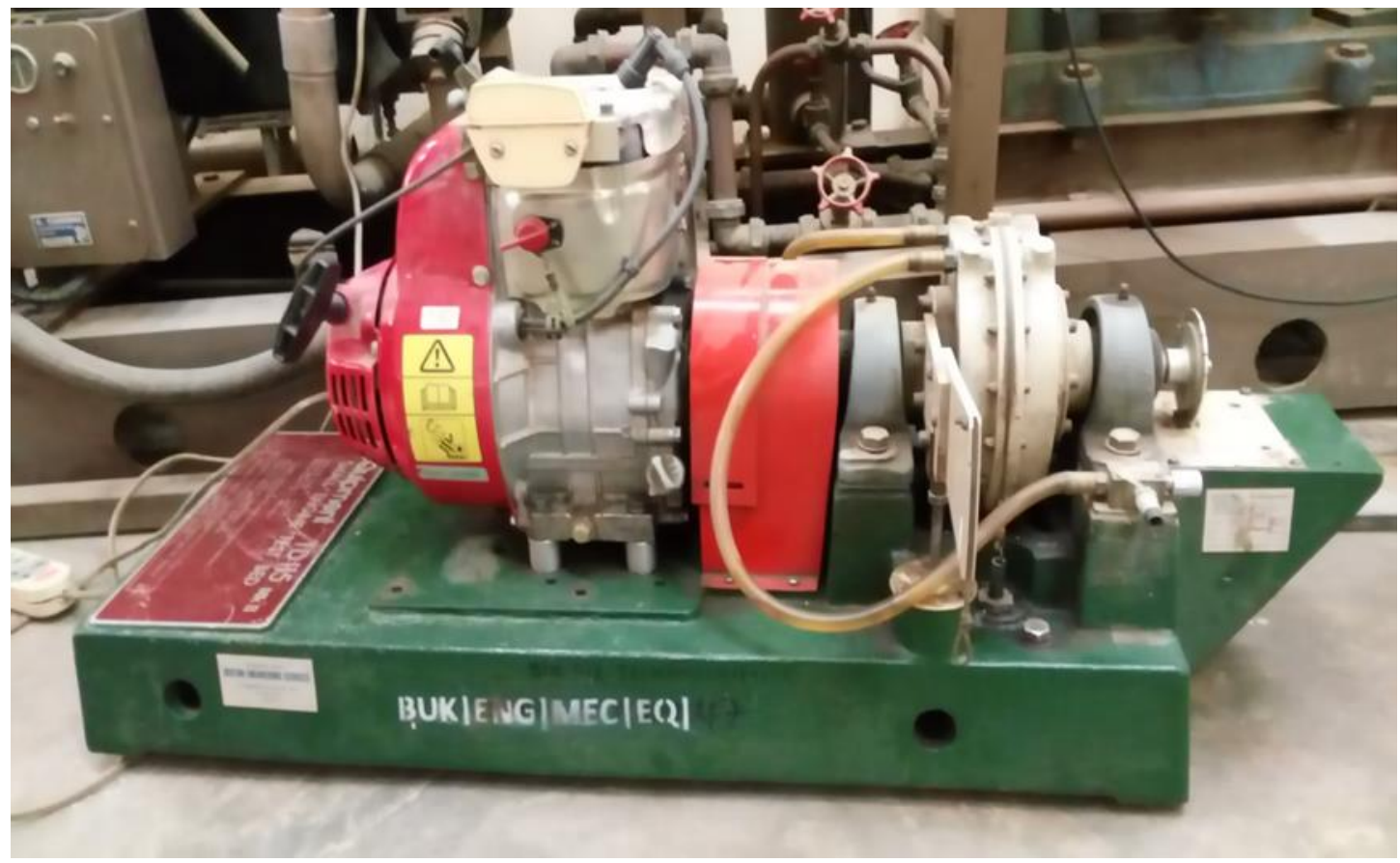

Figure 1. Honda G200K1 single-cylinder four-stroke gasoline engine

\subsection{Determination of brake power and the exergy efficiency at different torques}

This particular experiment was carried out to investigate the performance of the single-cylinder fourstroke gasoline engine run on different torques. It was firstly assumed that the reference environment is an ideal gas mixture whose composition on molar basis is thus: $\mathrm{CO}_{2}=0.03 \% ; \mathrm{N}_{2}=75.6 \% ; \mathrm{O}_{2}=20.35 \% ; \mathrm{H}_{2} \mathrm{O}$ $=3.12 \%$; other gases $=0.83 \%$ (Ibrahim et al., 2017). Before starting the tests, the engine was started and left 
to idle for about 10 minutes. It was then tested under 9.40, 9.50, 9.60 and 9.70 Newton-metre $(\mathrm{Nm})$ torque conditions at a constant speed of $2500 \mathrm{rpm}$.

The brake power was thereafter estimated using equation 1 :

$$
\begin{aligned}
& W=\frac{2 \pi T N}{60} \\
& \mathrm{~T}=\text { Torque } \\
& \mathrm{N}=\text { Engine Speed }
\end{aligned}
$$

Thereafter, the time taken for 3 litres of gasoline to be consumed was noted for the whole experiment. The engine was mounted on a test bench and its output shaft was connected to the rotor of a dynamometer which measures its torque, mechanical friction was used to brake the rotor.

During the engine test, the time taken for 3 litres of fuel to be completely exhausted was noted, this was then used to calculate the mass flow rate of the system. For that to be done, the volumetric flow rate (V) was first determined by dividing the volume (v) of gasoline consumed within the experimentation time, see equation 2 . The mass flow rate was thereafter estimated by multiplying the density of the fuel (obtained from table) with the estimated volumetric flow rate (equation 3).

$$
\mathrm{V}=\frac{v}{t}
$$

Hence,

$$
\dot{m}_{f}=\rho_{\text {avg }} \mathrm{V}
$$

For the determination of the exergetic efficiency of the engine, which the ratio of the engine's power output to its fuel exergy input for each torque was determined thus (Hacatoglu et al., 2014):

$$
\varepsilon_{1}=\frac{\dot{\mathrm{W}}}{\dot{m}_{f} e_{f}}
$$

Where

$$
e f=e_{t m}+e_{c h}
$$

ef $=$ specific exergy of steam

$e_{t m}=$ Thermomechanical exergy

$e_{c h}=$ Thermochemical exergy

The thermomechanical exergy can be determined thus (Sayin et al., 2007):

$$
\mathrm{e}_{\mathrm{tm}}=\overline{\mathrm{h}}-\overline{\mathrm{h}_{\mathrm{o}}}-\mathrm{T}_{0}\left(\overline{\mathrm{s}}-\overline{\mathrm{s}_{0}}\right)
$$

Where $\overline{\mathrm{h}}$ and $\overline{\mathrm{s}}$ signify the specific enthalpy and specific entropy of the fluid, respectively; $\overline{\mathrm{h}}_{0}$ and $\overline{\mathrm{s}_{0}}$ stand for the corresponding values of these properties when the fluid comes to equilibrium with the reference environment.

The specific chemical exergies also thermochemical exergy $\left(\mathrm{e}_{\mathrm{ch}}\right)$ of liquid fuels on a unit mass basis can be determined from the following relation (Seyedkavoosi et al., 2017).

$$
\mathrm{e}_{\mathrm{ch}}=\left[1.0401+0.1728 \frac{\mathrm{h}}{\mathrm{c}}+0.0432 \frac{\mathrm{o}}{\mathrm{c}}+0.2169 \frac{\mathrm{s}}{\mathrm{c}}\left(1-2.0628 \frac{\mathrm{h}}{\mathrm{c}}\right)\right] \times \mathrm{LHV}
$$

Where h, c, o and s are the mass fractions of Hydrogen, Carbon, Oxygen and Sulphur, respectively. $\mathrm{LHV}=44240 \mathrm{~kJ} / \mathrm{kg}=$ Lower heating value of gasoline $\left(\mathrm{C}_{10} \mathrm{H}_{22}\right)$ (Hudzik et al., 2014). 
Brake thermal efficiency (BTE) is the ratio of the brake power obtained from the engine to the fuel energy supplied to the engine. The BTE will determine how efficiently the heat is converted into work (Ramalingam and Rajendran, 2019). BTE is estimated thus:

The brake thermal efficiency for this engine was obtained using equation 8

$$
B T E=\frac{\dot{W}_{c v 2}}{Q_{c v}}
$$

Where

$$
\begin{gathered}
\dot{W}_{c v 2}=\text { brake output power } \\
\dot{Q}_{c v}=\text { The input energy to the gasoline engine }
\end{gathered}
$$

\subsection{Determination exergy destruction at different torques}

The relative humidity of the laboratory was first measured, the engine was loaded up to a certain torque while the speed remained constant, parameters like airspeed, temperature of fuel and exhaust gas, flow rate of the intake air were then measured and noted. The parameters obtained were used to determine the destruction at different torques when compared with the initial content of the fuel. The fuel content was obtained in the following manner: The empty measuring cylinder was taken for measurement on mass balance, gasoline was poured to $800 \mathrm{ml}$ level of the cylinder, and gasoline in the cylinder was taken to mass balance and the mass reading of gasoline together with the cylinder was taken. This experiment was repeated several times, and the average mass of the gasoline together with the cylinder was taken. The density of gasoline was then estimated, when compared to the density of gasoline in literature (Anuchi and Chukwu, 2017; Obodeh and Akhere, 2010), it was found that the gasoline is decane $\left(\mathrm{C}_{10} \mathrm{H}_{22}\right)$. Table 2 shows the thermophysical properties of decane (Nourozieh et al., 2013).

The exergy destruction using these thermophysical properties was calculated using the exergy balance equation:

$$
0=\left(1-\frac{T_{0}}{T_{j}}\right) \dot{Q_{c v}}-\dot{W}_{c v}+\dot{m}_{f} e_{f}-\dot{m}_{f} e_{e x}-\dot{E} d
$$

\begin{tabular}{|c|c|c|}
\hline Substance & $\bar{h}_{f}^{0}(\mathbf{k J} / \mathbf{k m o l})$ & $\bar{h}_{298 K}(\mathrm{~kJ} / \mathrm{kmol})$ \\
\hline $\mathrm{C}_{10} \mathrm{H}_{22}$ & $-249,659$ & \\
\hline $\mathrm{O}_{2}$ & 0 & 8682 \\
\hline $\mathbf{N}_{2}$ & 0 & 8669 \\
\hline $\mathrm{H}_{2} \mathrm{O}$ & $-241,820$ & 9904 \\
\hline $\mathrm{CO}_{2}$ & $-393,520$ & 9364 \\
\hline
\end{tabular}

Table 2. Thermophysical Properties

\subsection{Determination component of the G200K1 that is most influential on its efficiency}

Calculations for the exergy of the engine were done relative to the reference environment which had ideal gas properties: temperature $\left(\mathrm{T}_{0}\right)=298.15 \mathrm{~K}$, pressure $\left(\mathrm{P}_{0}\right)=1 \mathrm{~atm}$. Moreover, it is assumed that the reference point has an ideal gas mixture properties with the following composition on a molar basis: $\mathrm{N}_{2}=$ $75.6 \% ; \mathrm{O}_{2}=20.35 \% ; \mathrm{CO}_{2}=0.03 \% ; \mathrm{H}_{2} \mathrm{O}=3.12 \%$; other gases $=0.83 \%$ (Barelli et al., 2011; Moran et al., 2010). The exhaust gas is assumed to be a mixture of ideal gases, the thermomechanical exergy of the exhaust gas at the temperature $\mathrm{T}$ and pressure $\mathrm{p}$, and containing $\mathrm{n}$ components can be obtained from equation 10 (Sayin et al., 2007).

$$
e_{t m g}=\sum_{i=1}^{n} a_{i}\left\{\bar{h}_{i}(T)-\bar{h}_{i}\left(T_{0}\right)-T_{0}\left[\bar{S}^{0}(T)-\bar{S}^{0}\left(T_{0}\right)-R \ln \frac{p}{p_{0}}\right]\right\}
$$


Where: $\mathrm{R}=$ Gas constant; $\mathrm{T}_{\mathrm{o}}=$ Environment temperature; $\mathrm{p}=$ pressure of exhaust gases; $a_{i}=$ Molar amount of the gases; $\bar{h}_{i}(T)=$ Enthalpies at temperature of gases; $\bar{h}_{i}\left(T_{o}\right)=$ Enthalpies at environment temperature; $\bar{S}^{o}(T)=$ Entropies at temperature of gases; $\bar{S}^{o}\left(T_{o}\right)=$ Entropies at environment temperature.

\section{RESULT AND DISCUSSION}

\subsection{Average brake power and exergy efficiency}

Since brake power is a function of torque and speed, the speed of the engine was maintained at 2500 rpm throughout the engine test. Hence, different power values of brake power corresponding to the torques of 9.4, 9.5, 9.6 and 9.7 Nm were obtained as 2.46, 2.49, 2.51 and $2.52 \mathrm{~kW}$. The brake power $(\mathrm{kW})$ and exergy efficiency $(\%)$ at different torque values $(\mathrm{Nm})$ and airspeeds $(\mathrm{m} / \mathrm{s})$ were obtained (see table 3$)$. From the table, it can be seen that as torque increases, other parameters like air velocity, brake power and exergy efficiency also increase. Since higher exergy efficiency means higher energy quality used in a thermodynamic system which then makes the system more sustainable (Caliskan and Hepbasli, 2011), therefore, can be said that the single cylinder 4 stroke gasoline engine is more efficient when loaded. To buttress this point, the effect of engine load and reversible work on the rate of efficiency was estimated, the engine loads were varied from $20 \%$ to $100 \%$ at increments of $10 \%$. The result shows that for every $10 \%$ change in torque there is at least $2.62 \%$ change in brake power output at a constant speed of $2500 \mathrm{rpm}$, the relationship is a straight-line graph with equation $y=3.8168 x+0.0073$.

Table 3. Brake power and exergy efficiency

\begin{tabular}{|c|c|c|c|}
\hline $\begin{array}{c}\text { Torque } \\
\mathbf{( N m})\end{array}$ & $\begin{array}{c}\text { Air Velocity } \\
(\mathbf{m} / \mathbf{s})\end{array}$ & $\begin{array}{c}\text { Brake Power } \\
\mathbf{( k w )}\end{array}$ & $\begin{array}{c}\text { Exergy Efficiency } \\
\mathbf{( \% )}\end{array}$ \\
\hline 9.40 & 0.50 & 2.4609 & 17.07 \\
\hline 9.50 & 0.51 & 2.4871 & 17.25 \\
\hline 9.60 & 0.51 & 2.5133 & 17.43 \\
\hline 9.70 & 0.52 & 2.5395 & 17.62 \\
\hline
\end{tabular}

\subsection{Brake thermal efficiency and exergy efficiency}

The brake thermal efficiency (\%) and exergy efficiency (\%) at toque values $(\mathrm{N} / \mathrm{m})$ and airspeeds are presented in table 4 . It can be seen that as torque increases, other parameters like air velocity, brake thermal and exergy efficiency increase too. This is an indication that torque is the most influential parameter affecting the efficiency of a single-cylinder four-stroke gasoline engine, this finding concurs with that of other researchers who have worked on other types of engines (Ghazikhani et al., 2014; Parlak, 2005; Yamin et al., 2018).

Table 4. Brake thermal and exergy efficiency

\begin{tabular}{|c|c|c|c|}
\hline $\begin{array}{c}\text { Torque } \\
(\mathbf{N m})\end{array}$ & $\begin{array}{c}\text { Air Velocity } \\
\mathbf{( m / s )}\end{array}$ & $\begin{array}{c}\text { Exergy Efficiency } \\
\mathbf{( \% )}\end{array}$ & $\begin{array}{c}\text { Brake Thermal Efficiency } \\
\mathbf{( \% )}\end{array}$ \\
\hline 9.40 & 0.50 & 17.07 & 27.46 \\
\hline 9.50 & 0.51 & 17.25 & 27.76 \\
\hline 9.60 & 0.51 & 17.43 & 28.05 \\
\hline 9.70 & 0.52 & 17.62 & 28.35 \\
\hline
\end{tabular}


Figure 2 is a graph of torque against brake thermal efficiency, the relationship between the two is linear with equations $y=0.3378 x+0.1231$. The highest brake thermal efficiency $(28.35 \mathrm{kw})$ is obtained at a torque of $9.70 \mathrm{Nm}$ at a constant $2500 \mathrm{rpm}$. For every $10 \%$ rise in torque, there is a $30 \%$ rise in brake thermal efficiency.

It can be seen that the exergy transferred out of the system by the exhaust gases is very high as a result of the very high temperature of the flue gases, and the higher the temperature of the engine surface from where the heat is rejected thus a high exergy loss (thermochemical exergy of exhaust gases) because of this. The uncounted exergy shows the proportion of the exergy destroyed as a result of unrecoverable and uncounted losses in the whole engine such as combustion losses, friction loss, heat loss to lubricating oil, power consumed by auxiliary equipment e.g. pumps, radiation losses, thermal mixing losses etc. Exergy loss caused by irreversible combustion has a large proportion. Fuel combustion is a strongly irreversible process, although chemical energy is converted into thermal energy in the combustion process, and the quantity of energy is constant in conversion and transfer processes, exergy is reduced greatly. Furthermore, the higher the combustion temperature, the higher the potential for NOx formation in the combustion process is.

In addition, high temperatures of combustion cause increased heat transfer from the engine cylinder, consequently increasing the exergy lost as a result of the high heat transfer rate/heat loss. Temperature gradient is the driving force of heat transfer, it is an irreversible process where heat is transferred due to temperature difference, hence, exergy is lost in the process. Loss in exergy due to heat transfer is as a result of temperature gradient, the greater the gradient, the greater the exergy loss. The smaller the temperature gradient, the smaller the exergy loss.

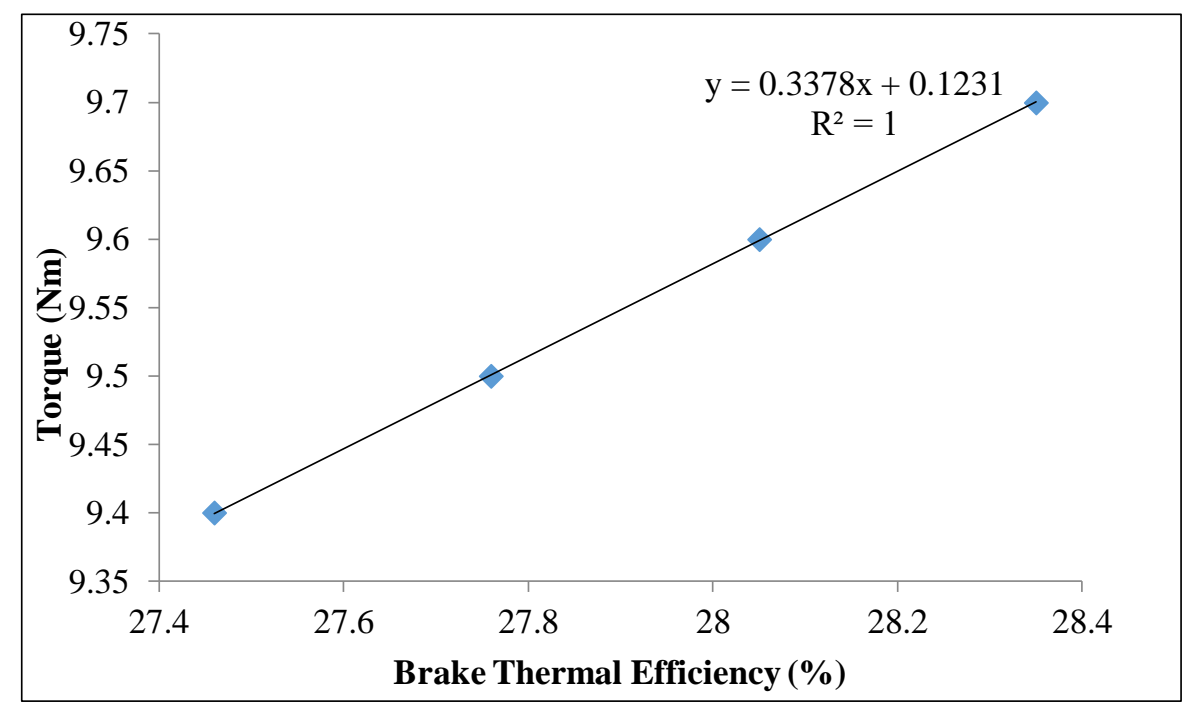

Figure 2. Graph of Torque against Brake thermal efficiency

\subsection{Torque and exergy destruction}

The exergy destruction $(\mathrm{kW})$ at different values of torques and airspeeds are presented in table 5 . From the table, as torque increases, other parameters like air velocity, exergy destruction ( $\mathrm{kW}$ ) increases too. The higher the value of torque, the higher the exergy destruction in the system, this is because the useful energy contained in the fuel is being converted to mechanical work (movement of the piston) and heat. This finding is further expatiated graphically by the illustration in Figure 3. It can be seen that torque has a direct impact on exhaust exergy, at the lowest torque of this research work $(2.40 \mathrm{Nm})$ the exhaust exergy lost is $29.779 \mathrm{~kW}$ at constant speed $2500 \mathrm{rpm}$. While at the highest torque of $2.70 \mathrm{Nm}$, the exhaust exergy lost is $29.857 \mathrm{~kW}$. The relationship is a straight-line graph with equation $\mathrm{y}=3.8462 \mathrm{x}-105.13$ which tells us 
that as torque increases exhaust exergy loss increases too. To minimise exhaust exergy loss, lower torque is required.

Comparing the exergetic efficiency (rate of exergy loss accompanying heat loss) of the system to the variation in torque, a similar pattern was noticed - the exergetic efficiency increases as torque increases. The linear graph relationship with equation $y=0.5464 x+0.0749$ is represented in Figure 4 . It was found that maximum exergetic efficiency $(17.62 \%)$ is obtained at $9.70 \mathrm{Nm}$ torque and that for every $10 \%$ rise in torque there is an $18 \%$ rise in exergetic efficiency at $2500 \mathrm{rpm}$ but this value may change at different speed operations.

Table 5. Exergy destruction

\begin{tabular}{|c|c|c|}
\hline $\begin{array}{c}\text { Torque } \\
\mathbf{( N m})\end{array}$ & $\begin{array}{c}\text { Air Velocity } \\
\mathbf{( m / s )}\end{array}$ & $\begin{array}{c}\text { Exergy Destruction } \\
\mathbf{( k W )}\end{array}$ \\
\hline 9.40 & 0.50 & -29.779 \\
\hline 9.50 & 0.51 & -29.805 \\
\hline 9.60 & 0.51 & -29.830 \\
\hline 9.70 & 0.52 & -29.857 \\
\hline
\end{tabular}

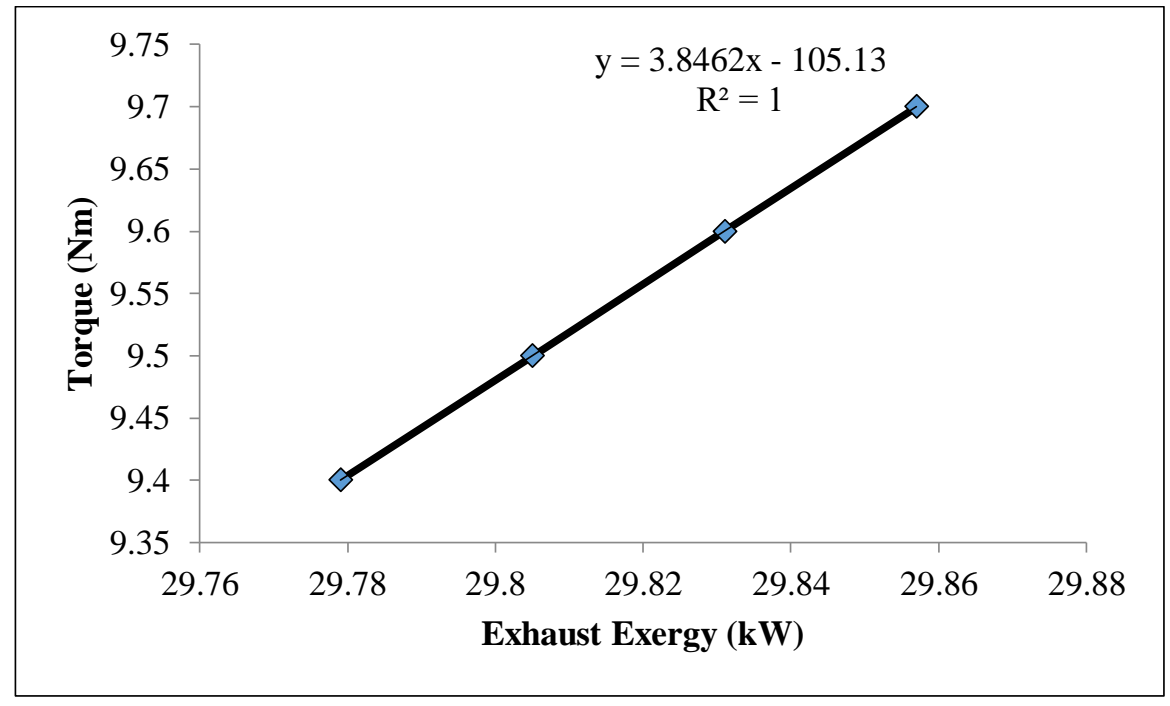

Figure 3. Graph of Torque against Exhaust Exergy 


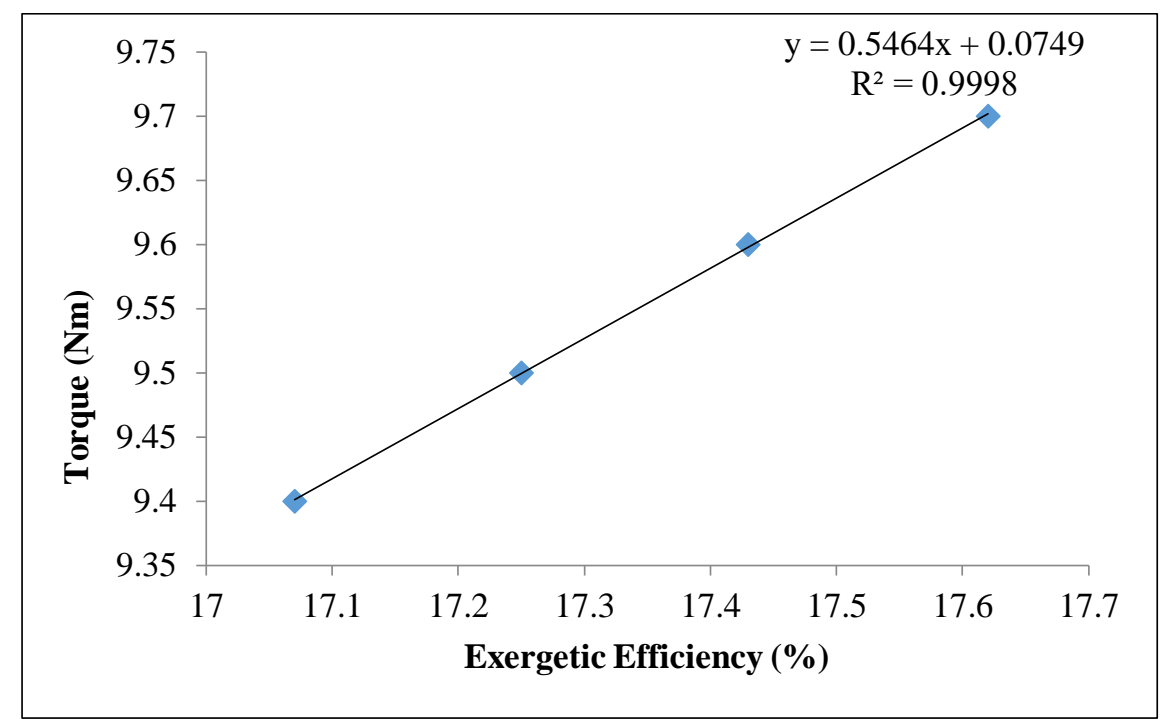

Figure 4. Graph of Torque against Exergetic efficiency

\section{CONCLUSION}

An exergy analysis was carried out on a Single-cylinder, four-stroke G200K1 gasoline engine at the Mechanical Engineering thermodynamic laboratory of Bayero University, Kano. Using the data gathered, the exergy balance relationship and exergetic efficiency were determined. It was found that the reversible work, irreversibility and exergy efficiency of a single-cylinder four-stroke engine increases with an increase in torque, this was demonstrated when the engine load was varied from $20 \%$ to $100 \%$. It was also found that for every $10 \%$ rise in torque, there is a corresponding increase in other parameters such as exergy destroyed, and exergy efficiency. On the efficiency of the engine, it was found that the major part of wasted energy is the high-temperature gas released through the exhaust.

To improve the overall efficiency of a four-stroke single-cylinder gasoline engine, the exergy destruction due to combustion can be reduced by optimizing the combustion temperature, this can be done by using a material with low thermal conductivity to reduce heat loss from the combustion chamber.

\section{ACKNOWLEDGEMENT}

The authors appreciate the technical support rendered by the staff of Bayero University, Kano thermodynamics laboratory.

\section{NOMENCLATURE}

$a_{i}=$ Molar amount of the gases

BTE $=$ Brake thermal efficiency

$\varepsilon_{1}=$ exergetic effciency

$e_{c h}=$ Thermochemical exergy

$\dot{E} d=$ Exergy destruction

$\mathrm{e}_{\mathrm{f}}=$ Specific exergies of the fuel

$e_{t m}=$ Thermomechanical exergy

$e_{t m g}=$ Thermomechanical exergy of exhaust gases

$\overline{\mathrm{h}}_{0}=$ Specific enthalpy when fluid is at equilibrium with the reference environment

$\overline{\mathrm{h}}=$ specific enthalpy

$\dot{m}_{f}=$ Mass flow into the system

$\mathrm{N}=$ Engine Speed 
LHV = Lower heating value

$\mathrm{p}=$ pressure of exhaust gases

$\mathrm{R}=$ Gas constant

$\dot{Q}_{c v}=$ The input energy to the gasoline engine

$\overline{\mathrm{s}}=$ Specific entropy

$\overline{\mathrm{s}_{0}}=$ Specific entropy when fluid is at equilibrium with the reference environment

$\mathrm{t}=$ time

$\mathrm{T}_{\mathrm{o}}=$ Environment temperature

$\mathrm{T}=$ Torque

$\mathrm{v}=$ volume of gasoline consumed

$\mathrm{V}=$ volumetric flow rate

$W_{c v 2}=$ brake power output

$\rho_{\text {avg }}=$ average density

\section{REFERENCES}

Aliu, I., 2020, “Energy efficiency in postpaid-prepaid metered homes: Analyzing effects of socio-economic, housing, and metering factors in Lagos, Nigeria", Energy Efficiency,13(5), 853-869.

Ameri, M., Kiaahmadi, F., Khanaki, M., and Nazoktabar, M., 2010, “Energy and exergy analyses of a sparkignition engine", International Journal of Exergy, 7(5), 547-563.

Anuchi, S. O., and Chukwu, U. J., 2017, “Investigation of Heavy Organics Precipitation from Nigerian Crude Oil Residue Using Single n-Alkane Solvents", IOSR Journal of Applied Chemistry, 10(4), 2225.

Arango-Miranda, R., Hausler, R., Romero-López, R., Glaus, M., and Ibarra-Zavaleta, S. P., 2018, “An overview of energy and exergy analysis to the industrial sector, a contribution to sustainability", Sustainability, 10(1), 153-163.

Barelli, L., Bidini, G., Gallorini, F., and Ottaviano, A., 2011, “An energetic-exergetic analysis of a residential CHP system based on PEM fuel cell", Applied Energy, 88(12), 4334-4342.

Caliskan, H., and Hepbasli, A., 2011, "Exergetic cost analysis and sustainability assessment of an internal combustion engine", International Journal of Exergy, 8(3), 310-324.

Ghazikhani, M., Hatami, M., Ganji, D. D., Gorji-Bandpy, M., Behravan, A., and Shahi, G., 2014, “Exergy recovery from the exhaust cooling in a DI diesel engine for BSFC reduction purposes", Energy, $65,44-51$.

Hacatoglu, K., Dincer, I., and Rosen, M. A., 2014, “Exergy analysis of a hybrid solar-wind-biomass system with thermal and electrical energy storage for a community" In Progress in exergy, energy, and the environment, 3-14.

Hudzik, J. M., Bozzelli, J. W., and Simmie, J. M., 2014, “Thermochemistry of C7H16 to C10H22 alkane isomers: Primary, secondary, and tertiary $\mathrm{C}-\mathrm{H}$ bond dissociation energies and effects of branching", The Journal of Physical Chemistry, 118(40), 9364-9379.

Ibrahim, T. K., Basrawi, F., Awad, O. I., Abdullah, A. N., Najafi, G., Mamat, R., and Hagos, F. Y., 2017, "Thermal performance of gas turbine power plant based on exergy analysis", Applied Thermal Engineering, 115, 977-985.

Liu, H., Ma, J., Tong, L., Ma, G., Zheng, Z., and Yao, M., 2018, "Investigation on the potential of high efficiency for internal combustion engines", Energies, 11(3), 11-20. https://doi.org/10.3390/en11030513

Modibbo, J. H., and Mary, F. O., 2017, “Impact of Commercial Tricycle Operation on Income of Youth in Mubi North Local Government Adamawa State Nigeria", IDOSR J Humanities Soc Sci, 2(2), 5672.

Moran, M. J., Shapiro, H. N., Boettner, D. D., and Bailey, M. B., 2010, Fundamentals of engineering thermodynamics (8th ed.). New York: John Wiley \& Sons. 
Nourozieh, H., Kariznovi, M., Guan, J. G., and Abedi, J., 2013. Measurement of thermophysical properties and modeling for pseudo-binary mixtures of n-decane and Athabasca bitumen. Fluid Phase Equilibria, 347, 62-75.

Obodeh, O., and Akhere, N. C., 2010, "Experimental study on the effects of kerosene-doped gasoline on gasoline-powered engine performance characteristics", Journal of Petroleum and Gas Engineering, 1(2), 37-40.

Rosen, M. A., 2021, "Exergy analysis as a tool for addressing climate change", European Journal of Sustainable Development Research, 5(2), 148-158.

Sayin, C., Hosoz, M., Canakci, M., and Kilicaslan, I., 2007, “Energy and exergy analyses of a gasoline engine", International Journal of Energy Research, 31(3), 259-273.

Seyedkavoosi, S., Javan, S., and Kota, K., 2017, “Exergy-based optimization of an organic Rankine cycle (ORC) for waste heat recovery from an internal combustion engine (ICE)", Applied Thermal Engineering, 126, 447-457.

Shaheen, S. A., and Lipman, T. E., 2007, "Reducing Greenhouse Emissions and Fuel Consumption Sustainable Approaches for Surface Transportation", International Association of Traffic and Safety Sciences, 3(1), 6-20. https://doi.org/10.1016/S0386-1112(14)60179-5

$\mathrm{Xu}$, M., Lin, B., and Wang, S., 2021, “Towards energy conservation by improving energy efficiency? Evidence from China's metallurgical industry", Energy, 216, 119-135.

Yamin, J. A., Sheet, E. A. E., and Hdaib, I., 2018, “Exergy analysis of biodiesel fueled direct injection CI engines", Energy Sources, Part A: Recovery, Utilization, and Environmental Effects, 40(11), 13511358. 